\title{
Analisis Pengaruh Persepsi Manfaat Dan Persepsi Kemudahan Terhadap Sikap Pengguna Sistem Online UNAI Menggunakan Metode TAM
}

\author{
Raymond Maulany dan Brenda Claudya \\ Fakultas Teknologi Informasi, Universitas Advent Indonesia
}

\begin{abstract}
Abstrak
Sistem Online yang mempunyai tujuan untuk meningkatkan efisiensi, efektifitas pengelolaan data dan untuk kepentingan pengambilan keputusan. Secara teoritis metode Technology Acceptance Model (TAM) banyak digunakan dalam penelitian untuk mengukur kesuksesan penerimaan sistem informasi berdasarkan pengguna dalam menggunakan sistem informasi. Dengan metode tersebut digunakan untuk menganalisis penerimaan Sistem Online di Universitas Advent Indonesia. Digunakan sampel sebanyak 95 responden dengan teknik pengambilan sampel yaitu purposive sampling dan perhitungan sampel dengan rumus slovin. Data dikumpulkan melalui kuesioner dan teknik analisis menggunakan analisis regresi linier berganda. Adapun tujuan penelitian ini adalah: (1) Untuk mengetahui persepsi manfaat berpengaruh terhadap sikap pengguna, (2) Untuk mengetahui pengaruh persepsi kemudahan berpengaruh terhadap sikap pengguna. (3) Untuk mengetahui pengaruh persepsi manfaat dan persepsi kemudahan terhadap sikap pengguna. Hasil penelitian menunjukkan bahwa (1) persepsi manfaat pada Sistem Online secara parsial tidak mempengaruhi sikap pengguna, (2) persepsi kemudahan pada Sistem Online secara parsial mempengaruhi sikap pengguna, dan (3) secara simultan persepsi manfaat dan persepsi kemudahan mempengaruhi sikap pengguna Sistem Online.
\end{abstract}

Kata - kata kunci: sistem online, Persepsi Manfaat dan Kemudahan, technology acceptance model

\section{Analysis of the Effect of Perception on Benefits and Ease Perception Towards UNAI Online System User Attitudes Using the TAM Method}

\begin{abstract}
Online system that has the aim to improve efficiency, effectiveness of data management and for the benefit of decision making. Theoretically the Technology Acceptance Model (TAM) method is widely used in research to measure the success of information system acceptance based on users in using information systems. With this method used to analyze the acceptance of the Online System at the Adventist University of Indonesia. A sample of 95 respondents was used with a sampling technique that is purposive sampling and sample calculation using the Slovin formula. Data were collected through questionnaires and analytical techniques using multiple linear regression analysis. The purpose of this study are: (1) To determine the perception of benefits affect the attitude of users, (2) To determine the effect of perceived ease of influence on user attitudes. (3) To determine the effect of perceived usefulness and perceived convenience on user attitudes. The results showed that (1) the perceived benefits of the Online System partially did not affect the user's attitude, (2) the perceived ease of the Online System partially affected the user's attitude, and (3) simultaneously the perceived usefulness and ease of perception influenced the attitude of the Online System users.
\end{abstract}

Keywords: Online System, Benefits and Ease Perception, Technology Acceptance Model

\section{Pendahuluan}

Perkembangan teknologi informasi dan komunikasi merupakan sesuatu yang tidak dapat dihindari oleh aspek kehidupan masyarakat. Saat ini teknologi informasi sudah banyak digunakan sebagai pendukung di berbagai lembaga pendidikan dalam melakukan proses bisnis. Salah satu faktor kemajuan suatu lembaga pendidikan adalah suatu sistem yang handal yang mendukung lembaga tersebut. Selain itu dukungan teknologi informasi untuk membantu lembaga tersebut dalam mengambil keputusan, dimana data disimpan di dalam database.

Sistem Online adalah sistem yang menerima langsung input dan menghasilkan output yang dapat diakses oleh umum dimana saja yang terhubung melalui internet/intranet. Universitas Advent Indonesia telah memiliki Sistem Online yang mempunyai tujuan untuk meningkatkan efisiensi, 
efektifitas pengelolaan data dan untuk kepentingan pengambilan keputusan. Secara teoritis metode Technology Acceptance Model (TAM) banyak digunakan dalam penelitian untuk mengukur kesuksesan penerimaan sistem informasi berdasarkan pengguna dalam menggunakan sistem informasi. Berdasarkan uraian diatas maka penulis tertarik untuk melakukan penelitian pada sistem di Universitas Advent Indonesia yang berjudul Analisis Pengaruh Persepsi Manfaat dan Persepsi Kemudahan Terhadap Sikap Pengguna Menggunakan Metode TAM.

\section{Landasan Teori \\ Sistem Informasi}

Sistem informasi adalah suatu sistem didalam suatu organisasi yang mempertemukan kebutuhan pengelolaan transaksi harian, mendukung operasi, bersifat manajerial, dan kegiatan strategi dari suatu organisasi dan menyediakan pihak luar tertentu dengan laporan-laporan yang dibutuhkan.

\section{Metode Technology Acceptance Model}

Model penerimaan teknologi Technology Acceptance Mode/ atau TAM merupakan suatu model penerimaan sistem teknologi informasi yang akan digunakan oleh pemakai. Model penerimaan teknologi atau Technology Acceptance Model (TAM) dikembangkan oleh Davis et al. (1989) berdasarkan model Theory of Reasoned Action atau TRA. Model TRA dapat diterapkan karena keputusan yang dilakukan oleh individu untuk menerima suatu teknologi sistem informasi merupakan tindakan yang dapat dijelaskan dan diprediksi oleh niat perilakunya.

Model Theory of Reasoned Action secara luas telah digunakan oleh dalam penelitian psikologi sosial, yang menentukan perilaku intention. Menurut Therory of Reasoned Action kinerja spesifik perilaku seseorang ditentukan oleh niat dari perilaku tersebut, dan niat dan perilaku dipengaruhi oleh sikap dan norma subjektif orang tersebut. Technology Acceptance Model menggunakan TRA sebagai dasar teori untuk menjelaskan saling keterkaitan antara perceived usefulness, perceived ease of use, user attitude, dan behavioral intention.

\section{Konstruk-Konstruk TAM}

Technology Acceptance Model (TAM) yang pertama yang belum dimodifikasi menggunakan lima konstruks utama. Kelima konstruks ini adalah sebagai berikut:

1. Kegunaan persepsian (perceived usefulness). Konstruk tambahan yang pertama di TAM adalah kegunaan presepsian (perceived usefulness).

2. Kemudahan penggunaan persepsian (perceived ease of use). Kemudahan penggunaan persiapan ( perceived ease of use) didefinisikan sebagai sejauh mana seseorang percaya bahwa menggunakan suatu teknologi akan bebas dari usaha.

3. Sikap terhadap perilaku (attitude towards behavior) atau sikap menggunakan teknologi (attitude towards using technology).

4. Minat perilaku (behavioral intention) atau niat perilaku menggunakan teknologi (behavioral intention to use).

5. Perilaku (behavior) atau penggunaan teknologi sesungguhnya (actual technology use).

\section{Data}

Data adalah sesuatu yang diketahui atau dianggap dapat memberikan gambaran tentang suatu keadaan atau persoalan yang sudah terjadi dan akan terjadi.

\section{Populasi}

Populasi adalah wilayah generalisasi yang terdiri atas obyek/subyek yang mempunyai kualitas dan karakteristik tertentu yang ditetapkan oleh peneliti untuk dipelajari dan kemudian ditarik kesimpulan.

\section{Metodologi Penelitian \\ Analisis Sistem Berjalan}

Dari penelitian yang dilakukan untuk sistem yang dibuat diperlukan proses-proses yang mendukung kerja sistem tersebut, adapun prosesnya sebagai berikut:

1. Proses Login

2. Proses Informasi Keuangan

3. Proses Informasi Kafetaria 

4. Proses Informasi Layanan Internet
5. Proses Informasi Absensi
6. Proses Informasi Grade/Nilai
7. Proses Poin
8. Proses Evaluasi Dosen
9. Proses Pendaftaran
10. Proses Informasi Jadwal Kelas
11. Proses Ganti Password
12. Proses Logout

\section{Tahapan Penelitian}

Adapun tahapan penelitian adalah :

1. Mengidentifikasi dan merumuskan masalah

2. Merumuskan hipotesis

3. Pengumpulan data

4. Menganalisis data dan Pembahasan

5. Kesimpulan dan Saran

\section{Variabel Penelitian}

Variabel-variabel yang digunakan dalam penelitian ini meliputi:

1. Variabel bebas (Variable Independent) Dalam penelitian ini yang menjadi variabel bebas yaitu persepsi manfaat menggunakan Sistem Online (X1), persepsi kemudahan menggunakan Sistem Online (X2).

2. Variabel Terikat (Variable Dependent) Dalam penelitian ini yang menjadi variabel terikat yaitu sikap dalam menggunakan Sistem Online (Y).

\section{Populasi dan Sampel}

Di dalam penelitian ini penulis menggunakan metode pengambilan sampel adalah menggunakan Sampling Purposive yaitu teknik pengumpulan sampel dengan pertimbangan tertentu (Sugiyono 2015:126).

Didalam penetapan ukuran sampel menggunakan cara pengukuran teknik Slovin.

$$
n=\frac{N}{1+\left(N e^{2}\right)}
$$

Dimana:

$\mathrm{n}=$ Ukuran Sampel

$\mathrm{N}=$ Populasi

$\mathrm{e}=$ Persentase kesalahan yang ditolerir dalam pengambilan sampel, pada kasus ini menggunakan $\mathrm{e}=$ $10 \%(0,1)$

$$
n=\frac{1871}{1+1871(0,1)^{2}}
$$

$$
\begin{aligned}
& n=\frac{1871}{19,71} \\
& n=95
\end{aligned}
$$

Sampel dalam penelitian ini adalah pengguna Sistem Online di Universitas Advent Indonesia. Jumlah ukuran sampel sebanyak 95 responden. Dan menurut Roscoe dalam Sugiyono (2014:129) menyatakan bahwa ukuran sampel yang layak dalam penelitian adalah antara 30 sampai dengan 500 .

\section{Analisa Koefisien Korelasi}

Analisa korelasi guna untuk mencari arah dan kuatnya hubungan antara dua variabel atau lebih. Untuk menghitung nilai korelasi antara data pada masing-masing pertanyaan dengan skor total 
memakai rumus teknik korelasi product moment, yang rumus sebagai berikut:

$r=\frac{\mathrm{n}(\Sigma \mathrm{XY})-(\Sigma \mathrm{X} \cdot \Sigma \mathrm{Y})}{\sqrt{\left.\left[n \overline{\Sigma X^{2}}-(\Sigma X)^{2}\right] \overline{\sqrt{ } n \cdot \Sigma Y^{2}-(\Sigma Y)^{2}}\right]}}$

Keterangan :

$r \quad$ : nilai korelasi

$\mathrm{n} \quad$ : jumlah responden

$X \quad$ : skor setiap item

Y : skor total

$\mathrm{XY} \quad$ : skor setiap item $\mathrm{x}$ skor total

$\Sigma Y^{2} \quad$ : jumlah kuadrat skor total

$\Sigma X^{2} \quad$ : jumlah kuadrat skor item

$(\Sigma Y)^{2} \quad$ : kuadrat jumlah skor total

$(\Sigma X)^{2} \quad$ : kuadrat jumlah skor item

\section{Analisa Data}

\section{Profil Responden Penelitian}

Dalam penelitian ini dibagikan kuesioner kepada mahasiswa Universitas Advent Indonesia (UNAI) dan diperoleh 95 orang responden yang terdiri dari 29 orang responden Fakultas Ekonomi, 12 orang Fakultas Keperawatan, 18 orang Fakultas Teknologi Informasi, 9 orang Fakultas Filsafat, 18 orang Fakultas Pendidikan, 9 orang Fakultas MIPA. Isi Kuesioner adalah pertanyaan-pertanyaan mengenai persepsi manfaat, persepsi kemudahan dan sikap pengguna dalam penerimaan teknologi berjumlah 12 pertanyaan.

\section{Responden}

Didapatkan gambaran umum mengenai profil responden yang diklasifikasikan berdasarkan jenis kelamin dan usia. Hasil pengumpulan data dapat dirinci pada tabel berikut ini :

Tabel 1 Responden Berdasarkan Jenis Kelamin

\begin{tabular}{|c|l|c|c|}
\hline No & \multicolumn{1}{|c|}{$\begin{array}{c}\text { Jenis } \\
\text { Kelamin }\end{array}$} & Jumlah & $\begin{array}{c}\text { Presentase } \\
\text { (\%) }\end{array}$ \\
\hline 1. & Laki-laki & 46 & $48.42 \%$ \\
\hline 2. & Perempuan & 49 & $51.58 \%$ \\
\hline & Total & 95 & $100 \%$ \\
\hline
\end{tabular}

Tabel 2 Responden Berdasarkan Fakultas

\begin{tabular}{|l|l|l|}
\hline No & Fakultas & Frekuensi \\
\hline 1. & Ekonomi & 29 \\
\hline 2. & Keperawatan & 12 \\
\hline 3. & Teknologi Informasi & 18 \\
\hline 4. & Filsafat & 9 \\
\hline 5. & Pendidikan & 18 \\
\hline 6. & MIPA & 9 \\
\hline Total & & 95 \\
\hline
\end{tabular}




\section{Analisa Koefisien Korelasi}

Tabel 3 Hasil SPSS Koefisien Korelasi Model Summary

\begin{tabular}{|l|l|l|l|l|}
\hline $\begin{array}{l}\text { Mod } \\
\text { el }\end{array}$ & $R$ & $\begin{array}{l}\text { R } \\
\text { Square }\end{array}$ & $\begin{array}{l}\text { Adjusted R } \\
\text { Square }\end{array}$ & $\begin{array}{l}\text { Std. Error } \\
\text { of the } \\
\text { Estimate }\end{array}$ \\
\hline 1 &, $726^{a}$ &, 527 &, 517 & 2,03376 \\
\hline
\end{tabular}

a. Predictors: (Constant), X2, X1

Berdasarkan tabel di atas diperoleh angka R pada tabel di atas yaitu sebesar 0,726 menyatakan bahwa terjadi hubungan persepsi manfaat dan persepsi kemudahan terhadap sikap pengguna Sistem Online, yaitu sebesar 0,527 atau sebesar 72,6\% dengan tingkat "kuat" sesuai dengan kriteria interval koefisien.

\section{Uji F}

Tabel 4 Hasil SPSS Uji F

\begin{tabular}{|c|c|c|c|c|c|c|}
\hline \multicolumn{7}{|c|}{ ANOVA $^{a}$} \\
\hline & & Sum of Squares & Df & Mean Square & $\mathrm{F}$ & Sig. \\
\hline \multirow{3}{*}{1} & Regression & 424,799 & 2 & 212,399 & 51,352 &, $000^{\mathrm{b}}$ \\
\hline & Residual & 380,528 & 92 & 4,136 & & \\
\hline & Total & & 94 & & & \\
\hline
\end{tabular}

a. Dependent Variable: $Y$

b. Predictors: (Constant), X2, X1

Berdasarkan tabel diperoleh $\mathrm{F}$ hitung sebesar 51,352 . Dengan menggunakan tingkat keyakinan $95 \%, a=5 \%$, df 1 (jumlah variabel-1) $=2$, dan df $2(n-k-1)$ atau 95-2-1 = 92 ( $n$ adalah jumlah kasus dan $\mathrm{k}$ adalah jumlah variabel independen), hasil diperoleh untuk $\mathrm{F}$ tabel sebesar 3,095. Karena nilai $\mathrm{F}$ hitung > F tabel $(51,352>3,095)$, maka Ho ditolak, artinya ada pengaruh secara signifikan antara persepsi manfaat dan persepsi kemudahan secara bersama-sama terhadap sikap pengguna. Jadi dari penelitian ini dapat disimpulkan bahwa persepsi manfaat dan persepsi kemudahan secara bersamasama berpengaruh terhadap sikap pengguna pada Sistem Online di UNAI.

\section{Uji T}

Tabel 5 Hasil SPSS Uji T

\begin{tabular}{|c|c|c|c|c|c|c|}
\hline \multirow{2}{*}{\multicolumn{2}{|c|}{ Model }} & \multicolumn{2}{|c|}{ Unstandardized Coefficients } & \multirow{2}{*}{$\begin{array}{c}\text { Standardized } \\
\text { Coefficients } \\
\text { Beta }\end{array}$} & \multirow[t]{2}{*}{$\mathrm{t}$} & \multirow[t]{2}{*}{ Sig. } \\
\hline & & $\mathrm{B}$ & Std. Error & & & \\
\hline \multirow{3}{*}{1} & (Constant) & 1,888 & 1,417 & & 1,333 & , 186 \\
\hline & $\mathrm{X} 1$ &, 152 &, 091 & , 152 & 1,669 &, 098 \\
\hline & $\mathrm{x} 2$ & 726 & 106 & 623 & 6,853 & 000 \\
\hline
\end{tabular}

a. Dependent Variable: $Y$

1. Berdasarkan tabel diperoleh $\mathrm{t}$ hitung persepsi manfaat sebesar 1,669. Tabel distribusi t dicari pada $a=5 \%: 2=2,5 \%$ (uji 2 sisi) dengan derajat kebebasan (df) n- k-1 atau 95-2-1 = 92 ( $n$ adalah jumlah kasus dan $\mathrm{k}$ adalah jumlah variabel independen). Dengan pengujian 2 sisi (signifikansi $=0,025$ ) hasil diperoleh untuk $\mathrm{t}$ tabel sebesar 1,98609 . Nilai $\mathrm{t}$ hitung $<\mathrm{t}$ tabel $(1,669<1,986)$ maka Ho diterima. Artinya secara parsial tidak ada pengaruh signifikan antara persepsi manfaat dengan sikap pengguna. Jadi dari kasus ini dapat disimpulkan bahwa secara parsial persepsi manfaat tidak berpengaruh terhadap sikap pengguna pada Sistem Online UNAI.

2. Berdasarkan tabel diperoleh thitung persepsi kemudahan sebesar 6,853 . Tabel distribusi t dicari 
pada a $=5 \%: 2=2,5 \%$ (uji 2 sisi) dengan derajat kebebasan (df) n-k-1 atau 95-2-1 = 92 ( $\mathrm{n}$ adalah jumlah kasus dan $\mathrm{k}$ adalah jumlah variabel independen). Dengan pengujian 2 sisi (signifikansi $=0,025)$ hasil diperoleh untuk $t$ tabel sebesar 1,986 . Nilai t hitung $>$ t tabel $(6,853$ $>1,986)$ maka Ho ditolak. Artinya secara parsial ada pengaruh signifikan antara persepsi kemudahan dengan sikap pengguna. Jadi dari kasus ini dapat disimpulkan bahwa secara parsial persepsi kemudahan berpengaruh positif terhadap sikap pengguna pada Sistem Online UNAI.

\section{Analisa Regresi Linier Berganda}

Dari tabel diatas diketahui persamaan regresi sebagai berikut :

$$
\begin{aligned}
& Y=a+b 1 X 1+b 2 X 2 \\
& Y=1,888+0,152 X 1+0,726 \times 2
\end{aligned}
$$

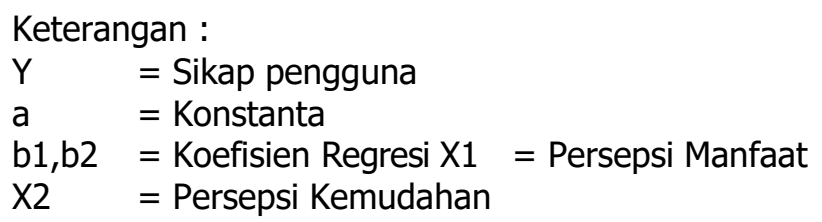

Dari persamaan diatas dapat diinterpretasikan sebagai berikut:

1. Diketahui konstanta besarnya 1,888 dengan koefisien manfaat (X1) dan kemudahan (X2) bernilai nol (0), maka diperoleh nilai Sikap pengguna sistem online sebesar 1.879 satuan. Ini berarti walaupun tanpa persepsi manfaat dan kemudahan sistem online nilai sikap pengguna sistem online tetap ada dan positif.

2. Diketahui Koefisien regresi persepsi manfaat (X1) sebesar 0,152 artinya bahwa peningkatan satu satuan persepsi manfaat dengan asumsi variabel bebas lain konstan akan menyebabkan peningkatan nilai sikap pengguna sebesar 0,152 unit. Koefisien bernilai positif artinya terjadi hubungan positif antara persepsi manfaat dengan sikap pengguna, semakin naik persepsi manfaat maka semakin naik sikap pengguna.

3. Diketahui Koefisien regresi persepsi kemudahan (X2) sebesar 0,726 artinya bahwa peningkatan satu satuan persepsi kemudahan dengan asumsi variabel bebas lain konstan akan menyebabkan peningkatan nilai sikap pengguna sebesar 0,726 unit. Koefisien bernilai positif artinya terjadi hubungan positif antara persepsi kemudahan dengan sikap pengguna, semakin naik persepsi kemudahan maka semakin meningkat sikap pengguna.

\section{Kesimpulan dan Saran \\ Kesimpulan}

Kesimpulan dari penelitian ini adalah:

1. Dari hasil perhitungan uji $t$, maka diperoleh nilai t hitung untuk persepsi manfaat (X1) sebesar 1,669, nilai t hitung untuk persepsi kemudahan (X2 ) sebesar 6,853, dan nilai t tabel sebesar 1,986. Hal ini berarti bahwa t hitung < t tabel dari persepsi manfaat, maka Ho diterima dan $\mathrm{Ha}$ ditolak yang berarti persepsi manfaat (X1) tidak berpengaruh secara parsial terhadap sikap pengguna (Y). Sedangkan t hitung > t tabel dari persepsi kemudahan, maka Ho ditolak dan $\mathrm{Ha}$ diterima berpengaruh secara parsial terhadap sikap pengguna $(Y)$.

2. Hasil perhitungan Uji $F$ yang dilakukan dengan program SPSS diperoleh nilai $F$ hitung sebesar 51,352. Nilai $F$ hitung ini lebih besar daripada $F$ tabel yaitu 3,095. Nilai signifikansi yang diperoleh adalah sebesar 0,000, nilai signifikansi ini lebih kecil daripada nilai a yaitu 0,05. Demikian Ho ditolak dan Ha diterima, artinya secara bersama persepsi manfaat dan persepsi kemudahan secara bersama-sama berpengaruh terhadap sikap pengguna pada Sistem Online di UNAI.

3. Berdasarkan tabel hasil uji T, yaitu persepsi kemudahan yang memiliki pengaruh sangat kuat terhadap sikap pengguna. Hal ini dapat dilihat pada nilai beta variabel manfaat adalah 0,152 dan nilai beta variabel kemudahan 0,726. Menarik kesimpulan bahwa nilai beta variabel persepsi kemudahan lebih besar dari nilai beta variabel persepsi manfaat. 


\section{Saran}

Adapun saran-saran yang diajukan berdasarkan hasil penelitian adalah sebagai berikut:

1. Sistem Online sudah memiliki banyak manfaat dan kemudahan. Namun disarankan membuat menu atau tampilan yang bervariasi yang meningkatkan sikap pengguna dalam Sistem Online sehingga pengguna tidak bosan dengan menu dan tampilan Sistem Online UNAI.

2. Disarankan untuk ditambahkan analisis Technology Acceptance Model dengan tambahan konstruk minat perilaku dan bagaimana pengaruh atau hubungannya dengan minat perilaku.

3. Dilakukan penelitian terkait dengan model lain serta lebih diarahkan kepada upaya pemilihan topik penelitian berbasis masalah dan inovatif agar dapat melihat apa sebenarnya masalah dilapangan dan mengapa tujuannya tersebut tidak tercapai. Sehingga pencapaian kemudahan dan manfaat Sistem Online terhadap pengguna terlaksana dengan baik.

\section{Referensi}

1. Bertrand, M., \& Bouchard, S. (2008). Applying the technology acceptance model to VR with people who are favorable to its use. Journal of CyberTherapy \& Rehabilitation, 1 (2), 200-207.

2. Calisir, F., Atahan, L., \& Saracoglu, M. (2013). Factors Affecting Social Network Sites Usage on Smartphones of Students in Turkey. Proceedings of the World Congress on Engineering and Computer Science, 2, 1-5.

3. Dalimunthe, Wibisono. (2013). Analisis Penerimaan Sistem E- Learning SMK Labor Pekanbaru dengan menggunakan metode Technology Acceptance Model (TAM), Jurnal Sains, Teknologi, dan Industri,11(1), 3-4.

4. Fatmasari, Ariandi.(2013). Penerimaan Metode Technology Acceptance Model (TAM) terhadap Penerimaan KRS Online, Jurnal IImiah Matrik, 16(2), 3-5. Hutahaean, Jeperson. (2015). Konsep Sistem Informasi. Edisi 1. Yogyakarta : Deepublish.

5. Lin, K.Y., \& Lu, H. P. (2011). Why people use social networking sites: An empirical study integrating network externalities and motivation theory. Journal Science and Technology, 27 (43), 1152-1161.

6. Lestari, Wiwik. (2013). Pengujian Technology Acceptance Mode/(TAM) Kasus pada penerapan sistem informasi tugas akhir (SITA) di UNEJ, Universitas Jember, 02 Desember 2013, hal 1-31.

7. Misbahudin, Hasan, I. (2013). Analisis Data Penelitian dengan Statistika Edisi Ke-2. Jakarta: Bumi Aksara.

8. Pikkarainen, T., Pikkarainen, K., Karjaluoto, H., \& Pahnila, S. (2004). Consumer acceptance of online banking: an extension of the technology acceptance model. Internet research, 14 (3), 224-235.

9. Riduwan. (2012). Dasar-Dasar Statistika. Cetakan Kesepuluh. Bandung: Alfabeta.

10. Riduwan. (2014). Metode dan Teknik Menyusun Tesis. Bandung: Alfabeta.

11. Rosa, A.S., dan M. Shalahudin. (2013). Rekayasa Perangkat Lunak Terstruktur dan Berorientasi Objek. Bandung: Informatika.

12. Rose, R. C., Kumar, N., \& Wemyss, G. P. (2009). Empirical Evaluation of the Electronic Procurement System Acceptance in Malaysia. European Journal of Scientific Research, 29 (1), 100-112.

13. Sago, B. (2013). Factors influencing social media adoption and frequency of use: An examination of Facebook, Twitter, Pinterest and Google +. International Journal of Businessand Commerce.

14. Seputra, Y. E. (2013). Belajar dan Analisis Tuntas Statiska Berbasis Komputer Jakarta: Mitra Wacana Media.

15. Sugiyono. (2012). Metode Penelitian Kuantitatif, Kualitatif, dan R\&D. Bandung: Alfabeta.

16. Sugiyono. (2013). Metode Penelitian Kuantitatif, Kualitatif, dan R\&D. Bandung: Alfabeta.

17. Sulistyaningsih, M., Tambotoh, J. J. C., Tanamaah, A. R. (2014). Technology Acceptance Model And Online Learning Media: An empirical study of online learning application in a private Indonesian University. Journal of Theoretical \& Applied Information Technology, 69 (1), 136143.

18. Syachriani, Sali. (2014). Analisis Penerimaan Sistem Informasi Kepegawaian dan Pengaruhnya terhadap Kinerja Pengguna, Konferensi Nasional Sistem Informasi 2014, STMIK Dipanegara Makassar, 27 Februari-01 Maret 2014, hal 1859-1863.

19. Sujarweni, V. W. (2015). SPSS Untuk Penelitian. Yogyakarta: Pustaka Baru Press. 
20. Widyaharsana, James. Indra W. (2010). Mobile Marketing Sebagai Media Pemasaran. Jakarta: PPM.

21. Yakub. (2012). Pengantar Sistem Informasi. Graha Ilmu: Yogyakarta. 